\title{
The Posthuman as Hollow Idol: A Nietzschean Critique of Human Enhancement
}

\author{
CIANO AYDIN* \\ University of Twente, Enschede, The Netherlands
}

*Address correspondence to: Ciano Aydin, PhD, Department of Philosophy, University of Twente, Drienerlolaan 5, 7522 NB, Enschede, The Netherlands. E-mail: c.aydin@utwente.nl

In this paper, the author aims to show that transhumanists are confused about their own conception of the posthuman: transhumanists anticipate radical transformation of the buman through technology and at the same time assume that the criteria to determine what is "normal" and what is "enhanced" are univocal, both in our present time and in the future. Inspired by Nietzsche's notion of the Overbuman, the author argues that the slightest "bistorical and phenomenological sense" discloses copious variations of criteria, both diachronic and synchronic, for what can be considered "normal" and "enhanced." Radical transformation through technology does not simply enable us to become "stronger," "smarter," or "bealthier," but it can and often will also change the very standard or yardstick with which we measure what counts as "stronger," "smarter," or "healthier." Put yet differently: new and emerging technologies are not neutral means but often bring about different and, from our current perspective, foreign standards for determining what are "normal" and "enhanced" capacities. Since the qualitative meanings of these terms are themselves not fixed, it is unintelligible and too reassuring to simply predict that new technologies will enhance buman beings.

Keywords: human enhancement, Nietzsche, Overhuman, postbuman, transhumanism

The last thing $I$ would promise would be to "improve” humanity. I won't be setting up any new idols; let the old ones learn what it means to have feet of clay.

Nietzsche, 2007, Twilight of the Idols, 71

(c) The Author 2017. Published by Oxford University Press, on behalf of the Journal of Medicine and Philosophy Inc. All rights reserved. For permissions, please e-mail: journals.permissions@oup.com 


\section{INTRODUCTION}

Transhumanists believe that technology could transform the human into a so-called posthuman, a technically enhanced future ideal being. Recent contributions to the human enhancement debate have wondered whether Nietzsche would be an advocate of transhumanism and whether his notion of the Overhuman (Übermensch) would strengthen transhumanists' notion of the posthuman. ${ }^{1}$ Some authors claim that his philosophy fits well in the transhumanists' mode of thought. Although Nietzsche focuses on education, Sorgner (2009) holds that he would also have encouraged technological means to realize the Overhuman, since both procedures are structurally analogous. More (2010) emphasizes the importance that both Nietzsche and transhumanists grant to critical thinking, scientific inquiry, and self-transformation. He even states, referring to himself, that Nietzsche has directly influenced the founders of the transhumanist movement.

Other authors find it difficult to ally Nietzsche with transhumanist thought. According to Bostrom, transhumanism has, despite "some surface level similarities with the Nietzschean vision," as much or more in common with humanism, the Enlightenment, and liberalism (Bostrom, 2005, 4). Hauskeller (2010) believes that reconciling Nietzsche with transhumanism is impossible since Nietzsche has, he claims, contempt for all core humanist values and aspirations. Babich (2012) argues that transhumanism is but one more expression of the ascetic ideal, which is a life-negating belief that Nietzsche has contested throughout his writings.

Still other authors relate the transhumanist movement to Nietzschean aspirations but reject both as unacceptable ideologies. Habermas, who rejects every type of genetic enhancement, identifies transhumanists as "self-styled Nietzscheans," who are "intoxicated by science fiction" and breeding fantasies and believes that they only succeeded in "staging a media spectacle" (Habermas, 2003, 22).

The aim of this paper is neither to settle the (anachronistic) question of whether Nietzsche is a transhumanist nor is it Nietzsche-exegesis for its own sake. Instead, I will use Nietzsche's figure of the Overhuman to analyse and evaluate the transhumanists' posthuman. ${ }^{2}$ This investigation will reveal that transhumanists are confused about their own conception of the posthuman: transhumanists anticipate radical transformation of the human being through technology and, at the same time, assume that the criteria to determine what is "normal" and what is "enhanced" are univocal, both in our present time and in the future. Inspired by Nietzsche's notion of the Overhuman, I will argue that the slightest "historical and phenomenological sense" undermines this essentialist perspective and discloses copious variations of criteria, both diachronic and synchronic, for what can be considered "normal" and "enhanced." 
Radical transformation through technology does not simply enable us to become "stronger," "smarter," or "healthier," but it can and often will also change the very standard or yardstick with which we measure what counts as "stronger," "smarter," or "healthier." Put yet differently: new and emerging technologies are not neutral means but could bring about different and, from our current perspective, foreign standards for determining what are "normal" and "enhanced" capacities. Since the qualitative meanings of these terms are themselves not fixed, it is unintelligible and too reassuring simply to predict that new technologies will enhance human beings.

\section{TRANSHUMANISTS AND THEIR IDEAL HUMAN BEING}

Transhumanism

Although there are significant differences in preference, nuance, and radicalness, most influential transhumanists (More, 1990; Savulescu, 2001; Stock, 2002; Bostrom, 2003a; Harris, 2007) share a common ground. First of all, transhumanists believe that we should or even ought to enhance ourselves and/or humanity as such, which will require overcoming current limitations of the bodily or mental constitution of the human being (Parens, 1998; Naam, 2004; Garreau, 2005; Wilsdon and Miller, 2006). Transhumanists' examples of enhancement of physical capacities are: increasing strength and stamina, being more resistant to illnesses, and defeating aging. Mental enhancements include improvements of sensory perception, memory, imagination, mood, and self-esteem. In contrast to therapy, Bostrom and Roache claim, "enhancement interventions aim to improve the state of an organism beyond its normal healthy state" (Bostrom and Roache, 2008, 120).

Second, leading transhumanists think that transhumanism can be viewed as an extension of humanism, from which it is partially derived. According to More (1990), "[t]ranshumanism shares many elements of humanism, including a respect for reason and science, a commitment to progress, and a valuing of human (or transhuman) existence in this life rather than in some supernatural 'afterlife'." Transhumanists promote in compliance with humanism, says Bostrom (2003b, 4), "rational thinking, freedom, tolerance, democracy, and concern for our fellow human beings." Transhumanists do not abandon or leave humanism behind but attempt to realize humanist values by other means.

Third, transhumanists believe that in improving ourselves we are not limited to traditional humanist methods, such as discipline and education through oral or textual means. Rather, we can also use and should make widely available technologies that will radically modify and enhance our human nature. In the words of More:

Transhumanism differs from humanism in recognizing and anticipating the radical alterations in the nature and possibilities of our lives resulting from various sciences 
and technologies such as neuroscience and neuropharmacology, life extension, nanotechnology, artificial ultraintelligence, and space habitation, combined with a rational philosophy and value system. (More, 1990)

Other technologies that transhumanists focus on are: genetic engineering, prosthetics and powered exoskeletons, and tissue engineering. ${ }^{3}$

Fourth, many transhumanists expect that exponential technological progress will eventually enable us to move beyond what some would think of as "human." Quoting More (1990) again: "Transhumanism is a class of philosophies that seek to guide us towards a posthuman condition." According to Bostrom (2013), the idea of the posthuman being is based on the premise "that the human species in its current form does not represent the end of our development but rather a comparatively early phase." Some transhumanists also claim that so-called existential risks (global pandemic, comet impact, misuse of nanotechnology) compel us to evolve technologically, for the sake of our survival, into new and better humans (Bostrom, 2002, 2013).

\section{Transhumanists' Ideal Human Being}

To acquire deeper insight into the transhumanists' ideal or more ideal human being requires further understanding of what they mean by "enhancement." "Enhancement" is, as indicated above, often contrasted to therapy. "Therapy" is understood as repairing a bodily or mental defect, whereas "enhancement" is conceived as improving a healthy or normal bodily or mental constitution. "Therapy" aims at a transition from less normal to normal, whereas "enhancement" implies transition from normal to better than normal. A "transition from normal to better than normal" can have at least two different meanings: (1) improving qualities in some individuals that already exist in average people; (2) introducing improvements that no human being has yet displayed (Brey, 2008). ${ }^{4}$

These distinctions allow the categorization of human beings into four different, less and more ideal, types: the disabled, the enabled, the over-abled, and the differently-abled. The disabled lack certain bodily or mental functions, qualities, traits, or capacities, which can be found in average people (e.g., being blind, missing a limb, having a memory deficit). The enabled possess average people's functions, qualities, traits, or capacities (having an average IQ, living approximately 80 years, being able to appreciate good music). The over-abled have functions, qualities, traits, or capacities that can be found in average people but are much stronger, fine-tuned, or further developed (e.g., being able to run $100 \mathrm{~km}$ per hour, playing a very difficult instrument with virtuosity, processing and remembering huge amounts of information). Finally, the differently-abled are characterized by functions, 
qualities, traits, or capacities that no current human beings possess and that grant them an advantage over current human beings (X-ray vision, the ability to fly, seeing things in four dimensions, and other capacities unimaginable for us).

Transhumanists mostly focus on the last two types: the over-abled and the differently-abled. In Why I Want to be a Posthuman When I Grow Up, Bostrom (2008) describes the process of becoming a posthuman being. The improvements that Bostrom mentions indicate a continuity between what we already are or have and what we eventually might become or realize:

You have just celebrated your 170th birthday and you feel stronger than ever. Each day is a joy. You have invented entirely new art forms, which exploit the new kinds of cognitive capacities and sensibilities you have developed. You still listen to music-music that is to Mozart what Mozart is to bad Muzak. You are communicating with your contemporaries using a language that has grown out of English over the past century and that has a vocabulary and expressive power that enables you to share and discuss thoughts and feelings that unaugmented humans could not even think or experience. (Bostrom 2008, 5)

In sum: we will still have birthdays, many birthdays. Strength and joy will still be qualities that we find important. We will still appreciate music and have developed a highly sophisticated receptivity for it. We will still use language to communicate with one another, albeit this language will enable a much more refined expression of thoughts and feelings.

Although Bostrom does recognize that our ability to imagine posthuman life is very limited, he believes that it is not completely impossible to imagine how posthumanism will emerge: "As we seek to peer farther [sic] into posthumanity, our ability to concretely imagine what it might be like trails off . . Yet we can at least perceive the outlines of some of the nearer shores of posthumanity, as we did in the imaginary scenario above" (Bostrom, 2008, 5f).

That there is a continuity between the over-abled and differently-abled is further stressed by Bostrom's conviction that a person does not have to change substantially in his transformation into a posthuman being:

A person could obtain considerable increased life expectancy, intelligence, health, memory, and emotional sensitivity, without ceasing to exist in the process . . . these developments are not viewed as spelling the end of the original person . . . If most of what someone currently is, including her most important memories, activities, and feelings, is preserved, then adding extra capacities on top of that would not easily cause the person to cease to exist. (Bostrom 2003a, 499)

Bostrom $(2008,16)$ compares the transformation into a posthuman being to migration, career change, or religious conversion and believes that we should not use stricter criteria for technological self-transformation. We will have better and more capacities but could "still embrace most traditional values and principles of personal conduct" (Bostrom, 2003b, 7). 
This view is shared by most transhumanists. Hans Moravec characterizes the posthuman robot as our evolutionary heir: "Intelligent machines, which will grow from us, learn our skills, and share our goals and values, can be viewed as children of our minds" (Moravec, 1999, 126). Even Kurzweil's (2005) singularity, which marks a radical shift or conversion in the history of mankind, presumes continuity between the over-abled and differentlyabled. Exponential growth of technological know-how and accumulation of technological (ultra)intelligence underpin the singularity. The resulting ultraintelligent life forms, however, will share our moral values: "the nonbiological intelligence will be embedded in our society and will reflect our values" (Kurzweil, 2005, 424).

\section{NIETZSCHE'S OVERHUMAN}

The "Over" in "Overhuman"

One of the first questions that Nietzsche's notion of the Übermensch raises for English writers is: how should one translate this word? In some translations "Übermensch" is translated as "Superman." I prefer "Overhuman" to "Superman" for two reasons: first, it preserves the allusions and word play Nietzsche intends with his recurrent references to going under (going down, downfall) and going over (overcoming, transform). Second, "Superman" conjures up images of the comic book and motion picture characters that possess supernatural powers (Superman, Spiderman, Hulk, etc.). This association draws attention to certain extraordinary capacities and functions and passes over the "über" in "Übermensch," which is, I believe, of eminent importance for adequately understanding Nietzsche's proposed "ideal."

The "over" in "Overhuman" designates detachment above all. Although the Nietzsche literature provides divergent answers to what exactly Nietzsche wants to overcome, a persistent motive that can be detected throughout his work is that he wants to overcome the Platonic-Christian worldview (MüllerLauter, 1971; van Tongeren, 1989; Aydin, 2003). According to Nietzsche, Christianity has effectively rendered one possible interpretation of the human being absolute by subjecting him $^{5}$ to an unchanging moral value system that is sanctioned by an omnipotent and eternal God. The seeds for this ideology he traces back to Plato's Idea of the Good. That is why Nietzsche can say: "Christianity is Platonism for the "people"" (Nietzsche, 2002, 4). Plato's Idea of the Good forms the bedrock of the belief that the human being has an invariable and ahistorical essence, which should be cultivated according to certain universal values and norms.

Here, I have to emphasize the crucial role that power relations and struggle play in Nietzsche's worldview. His concept of "will to power" is characterized by intrinsic relationality: power is only power in relation to another power. Moreover, power is a necessary striving to expand itself. Power is 
only power insofar as it can maintain itself against other powers and strives to predominate over them. Since the world is "will to power' and nothing else," (Nietzsche, 2002, 36) nothing has existence and meaning outside the "game" of power relations, and existence and meaning can only emerge within the "game" of power relations. Because of this, there is also no possibility to withdraw from this "game." Even rejecting the claim that reality is will to power is an expression of will to power. Also, setting a standard or criterion in order to establish or measure what is "normal" and what is "enhanced" is nothing else than an expression of will to power, which always can be questioned by other wills to power. Weakening or desisting struggle by absolutizing one criterion or standard that once and for all fixes what is good, enhanced, or ideal (and, hence, not acknowledging other possible standards) is for Nietzsche "life threatening": it blocks the emergence of (new) life forms and (new) meanings (I will come back to this later on). This is exactly, Nietzsche believes, what the Platonic-Christian ideology is doing.

From this perspective, it is not very surprising that the features that Nietzsche attributes to the Overhuman stand in opposition to those that he identifies with the Platonic-Christian ideal. Against the Platonic-Christian desire for equality and a common value system, Nietzsche (2006, 78) endorses a world marked by inequalities and struggles. For him, the idea that all human beings are equal (in the sense of "similar") as buman beings and have, therefore, equal rights, values, and duties finds its source in the belief that human beings have a common essence that is secured by something or someone (for Nietzsche that is ultimately "God") that inscribes that essence in their nature. Human beings, according to Nietzsche, do not share a common essence. They should, therefore, not strive for similar worldviews and value systems but attempt to develop different life forms by continuously challenging the status quo.

Also, unlike the Platonic-Christian influenced masses who desire dependence and life within an inclusive herd, Nietzsche's Overhuman stands in splendid solitude (Nietzsche, 2006, 46). According to Nietzsche, the potential to establish radical new ways of living can only come from individuals who are not completely absorbed and exhausted by society and its Sittlichkeit der Sitte and have enough distance and power to challenge it (Nietzsche, 2006, 36; Aydin, 2008).

In contrast to the Platonic-Christian desire to dwell on the eternal and dismiss the earthly body and way of life, Nietzsche's Overhuman loves the body and its senses. ${ }^{6}$ In contrast to the soul, the body is not a unity but a multiplicity and does not exhibit eternal forms but change and fluidity (Nietzsche, 2006, 23f; Nietzsche, 2007, 167). Nietzsche diagnoses views that want to escape the here and now as symptoms of not being able to cope with the fact that life has no a priori universal meaning and goal. The body, he believes, could make us see and appreciate the multiplicity of life forms and the necessity to create meaning and establish new goals. In Nietzsche's 
words: "Along the guiding thread of the body. . .we learn that our life is possible through an interplay of many intelligences that are very unequal in value, and thus only through a constant, thousand-fold obeying and commanding" (Nietzsche, 2003, 30, 77).

At first sight the process of secularization seems to pave the road for the Overhuman: "God died: now we want-the overman to live" (Nietzsche, 2006, 232). In different passages, Nietzsche welcomes this development as liberation. Equality, he believes for example, can no longer be justified: "“we are all equal, human is human, before God-we are all equal!" Before God! -Now, however, this God has died. . .this god was your greatest danger" (Nietzsche, 2006, 232). Since God has functioned as an orientation point for how human beings understood themselves and lived their lives, with the death of God also the "human being" "dies": human beings become a problem for themselves, that is, how to define and understand "human nature" becomes a philosophical challenge. For Nietzsche, this "problem" or "challenge" brings new opportunities. The death of God renders an absolute criterion obsolete, enticing the human being to create his own values and, hence, be his own God (Nietzsche, 2006, 47). The death of God could liberate human beings from a uniform value system and open up a sea of interpretations and experiments, which could instigate radically new TS: world(view)s and new identities.

Unfortunately, the modern, secularized human being, Nietzsche believes, has not overcome the Platonic-Christian ideal. The religious "surface" has been peeled off, but the Platonic-Christian value system is preserved. The same normalizing and homogenizing tendencies can be detected in our modern culture. In democratic societies, for example, qualitative differences are considered to be bridgeable and are reduced to quantitative differences. The law has taken the place of God: "the democratic instincts of the modern soul! Everywhere, equality before the law" (Nietzsche, 2002, 22); "the democratic movement is the heir to Christianity" (Nietzsche, 2002, 90). The herd mentality is also reflected in socialist movements (Nietzsche, 2002, 92). In modern philosophy and science, the multiplicity that we find in the world is disregarded by assuming that reason can capture pure objectivity and find absolute truth, which is for Nietzsche nothing else than yet another expression of the Platonic-Christian disposition (Nietzsche, 2001, 6).

The process of modernization, which appears to have the potential to subvert the idea of an absolute criterion for determining what a human being is or ought to be, has not, in Nietzsche's opinion, been potentiated. For Nietzsche, democracy, liberalism, and also bumanism are, among many other modern ideologies, all guises of the tendency of the modern human being to canonize and eternalize his present state after the death of God. The modern, subject-centered rational individual finds universal criteria to determine what is true and right in an "inner-world," which increasingly makes "The Great Lawmaker" redundant. Secularization, for Nietzsche, even 
becomes an additional threat. There is nothing anymore that can relativize the belief system of the modern individual, not even a God. The human being finds the measure for understanding and determining his identity and his values, as well as the world, in himself. He becomes "the measure of all things." The human being has no other objective and destiny outside himself. The modern, Western individual imprisons himself in the self-glorification and self-deification of his present state. Other possible life forms are, hence, excluded. Nietzsche detects this tendency even in evolutionist perspectives, where the leading idea is not self-overcoming but self-preservation (Nietzsche, 2006, 232; Nietzsche, 2003, 134f, 257, 264).

This discovery is dramatically portrayed in Also sprach Zarathustra. After failing to convey his optimistic message of the Overhuman to the masses, Zarathustra attempts a different strategy: he warns them of what will happen if they are not willing to make the necessary preparations for the advent of the Overhuman. He tries to scare them by speaking to them of the "most contemptible person," the "last human," who is the Overhuman's antonym. The "last human" symbolizes not the will to overcome oneself but rather the will to preserve oneself. It symbolizes human beings who, in Nietzsche"s words, "no longer launch the arrow of their longing beyond the human" (Nietzsche, 2006, 9). To his surprise, Zarathustra discovers that his audience is not repulsed by the presented opposite scenario but rather recognizes itself in the last human (Nietzsche, 2006, 10). The modern, secularized individual is completely content with himself. The last thing that this individual wants is self-overcoming: "Each wants the same, each is the same, and whoever feels differently goes voluntarily into the insane asylum" (Nietzsche, $2006,10)$. Redemption from the acquiescence of invariability ("nihilism" is another word Nietzsche uses for this state of mind) seems to have become impossible.

The "Over" as an Index of Transcendence

The Overhuman is a name for something that should liberate us from both the Platonic-Christian heritage and the modernist path on which we have embarked. It promises to overcome the idea that an external measure determines our essence and values, as well as the view that we are the ones who determine this measure and, hence, our essence and values. The opposition between the Overhuman and the last human clearly shows that Nietzsche's concern is not only an episode in our history (Christianity). The "last human" rather expresses the persistent ("human, all too human") tendency to resign to a presumed invariable identity, whereas the Overhuman promises to undermine and overcome every possible invariability and sameness. This explains why Nietzsche can lump Platonism, Christianity, and humanism, which at first sight are very different ideologies, together. We will use Nietzsche's notion of the Overhuman to assess whether this tendency 
to assume univocal criteria to determine what is an "enhanced" or "ideal human" can also be detected in transhumanist views. The "humanist" dimension in transhumanism relates, therefore, to this essentialist tendency. Of course, this Nietzschean assessment might not apply to other possible types of "humanism."

Sometimes Nietzsche seems to give concrete examples of Overhumans: Napoleon, for example, is characterized as a "synthesis of Unmensch [brute] and Übermensch" (Nietzsche, 1997, 33). Cesare Borgia, another example, is called "a type of overman" (Nietzsche, 2007, 211). These identifications are, however, always relative and oppositional. Napoleon and Borgia represent "a type that is an overman in comparison" (Nietzsche, 2007, 101): they are Overhumans "in contrast to "modern" people, to "good" people, to Christians and other nihilists" (Nietzsche, 2007, 147). In Also sprach Zaratbustra, the question of whether there have been Overhumans is raised a couple of times. Zarathustra leaves no room for speculation: "Never yet has there been an overman" (Nietzsche, 2006, 71).

In Also sprach Zarathustra, this use of the opposite as a means to signify an Overhuman takes on many forms as humans fail again and again to meet Zarathustra's expectations, and the gap between all the types of humans that we can imagine and the Overhuman becomes ultimately unbridgeable. The Overhuman is portrayed as anti-ideal par excellence because it departs furthest from everything that we can imagine and comes nearest to the radically different. Even the higher human beings who become Zarathustra's "disciples" and demonstrate characteristics that stand in opposition to Christianity and the democratic, secularized ideal, are not fully identifiable as Overhuman. The last pope, for example, who was the incarnation of Christ himself, broke with God and claims that he is even more Godless than Zarathustra (Nietzsche, 2006, 209f.). Although these figures are Overhumans by comparison and contrast, they cannot be positively identified as Overhumans. If that were possible, the Overhuman would be yet another ideal that attempts to fix the human in a particular life form and value system, which is, as Nietzsche indicates, characteristic of all worldviews so far: "But have you ever asked yourselves properly how costly the setting up of every ideal on earth has been? How much reality always had to be vilified and misunderstood in the process" (Nietzsche, 1997, 65). Also, the higher human beings ultimately do not and cannot live up to Zarathustra's standards (Nietzsche, 2006, 264f.).

The Overhuman not only has never existed, but also will never exist, as something particular. It also can never be a human being with extraordinary characteristics, a kind of Superman, and certainly not an ideal-human as might be identified according to modern ideology. The Overhuman is portrayed in different ways as something that goes beyond every possible idea of a particular human. Every characterization of the Overhuman remains a negative indication. It lies, therefore, beyond every imaginable measure, 
which makes speaking of the Overhuman a highly paradoxical enterprise. By its very nature, the Overhuman cannot be conceptualized or realized. In fact, everything that is said about it is too much.

The Overhuman is a name for Nietzsche's conviction that the human being is not an end point but an in-between-being: "What is great about human beings is that they are a bridge and not a purpose: what is lovable about human beings is that they are a crossing over and a going under" (Nietzsche, 2006, 7). The prefix "über" in Übermensch indicates that the human being is an orientation without a beginning in a primary cause and an end in a final goal. Again: what is crucial is the über. It transcends every characterization. The Overhuman is a "transcending indication."

Nietzsche's notion of transcendence should not, however, be confused with traditional religious notions. It does not refer to an afterlife but tries to depict a fundamental dimension of our very earthly and bodily existence. This view is also expressed in Nietzsche's definition of the human being as the "not yet determined animal." This definition indicates that the human being "essentially" does not coincide with its actual state. By overcoming his present state, the human being does not alienate himself from his nature but does justice to what makes him human: becoming (Aydin, 2007). The human would cease to be human (and entirely reconcile itself with its animal part) if it were to coincide completely with its actual state. For Nietzsche, new technological developments do not represent the first time that the human being has been faced with the prospect of overcoming his actual state; ideally, this potential is his permanent condition.

From Nietzsche's perspective, human life can only recognize and justify itself by pursuing something that in no way can be reduced to but rather goes beyond its present state, even after the death of God. In Nietzsche's words: "It is not enough that you reconcile yourself with the one you kill [namely, yourself]. Let your sadness be love for the overman-thus you justify that you still live!" (Nietzsche, 2006, 26). The human being is a longing for something beyond himself, an "arrow and longing for the overman" (Nietzsche, 2006, 41). In something that he is not yet, the human being finds a justification for what he is and must become, which is also the only way to give meaning to his life.

\section{SOUNDING OUT HOLLOW IDOLS}

The figure of the Overhuman challenges the essentialist idea of one possible interpretation of the human, which denies and destroys the potential richness of human life (Nietzsche, 2007, 155). In Nietzsche's idiom, this assessment can be characterized as "sounding out of hollow idols," which is done with a "tuning fork." An idol is an ideal that "rob[s] reality of its meaning, value, and truthfulness," which is, according to Nietzsche, something that 
all essentialist worldviews do (Nietzsche, 2007, 71). Although at first sight the transhumanists' concept of posthuman seems to discard an essentialist view, Nietzsche's notion of the Overhuman reveals, as I will show in this section, that the transhumanists' ideal human being is at its core invariable, uniform, and independent, which are throughout the history of philosophy the three main aspects of an "essentialist" or "substantialist" approach (Stegmaier, 1977; Aydin, 2003). Transhumanists' account of the posthuman being is essentialist because they misunderstand and misrepresent, as I will show on the basis of Nietzsche's account of the human and Overhuman, the very "nature" of the human.

\section{The Invariable Posthuman}

Predictions and anticipations of radical change in the constitution of the human being, as expressed by terms like "the singularity," suggest that transhumanists adopt an anti-essentialist anthropological framework. But, on reflection, their view is rather conservative: transhumanists want a very specific and restricted "radical" change. 7 They want, as we have seen, humans to improve radically their functions and capacities using new and emerging technologies, without changing or jeopardizing their humanist values and goals. Those values and goals secure unequivocal criteria for what can be considered "enhancement."

Within that unequivocal humanist framework, causal relations are then drawn between preferred values, capacities that can contribute to realizing those values, and human enhancement technologies that could improve those capacities. This is done in the following way: (1) value $\mathrm{x}$ is identified as an intrinsic or at least as an indisputable preferred value; (2) capacity y is identified as an important capacity that affects value $\mathrm{x}$, in the form: value $\mathrm{x}$ can be better realized by improving capacity y; technology $\mathrm{z}$ is identified as a technology that affects capacity $y$, in the form: technology $z$ can improve capacity y. Technology z can then be qualified as a "human enhancement technology" because (1) it can improve capacity y, which in its turn (2) can significantly contribute to realizing value $\mathrm{x}$, which (3) is identified as a preferred value.

To illustrate how particular technologies are in this way qualified as "human enhancement technologies," I give three examples: Inserting a brain implant for extra information storage can be considered as a human enhancement technology, because (1) inserting a brain implant for extra information storage can improve (inter alia) memory, (2) improving memory can improve (inter alia) rational thinking, and (3) rational thinking is identified as a preferred value. Genetic manipulation can be considered as a human enhancement technology, because (1) genetic modification can improve (inter alia) deductive/logical competence, (2) improving deductive/logical competence can enhance (inter alia) autonomy, and (3) autonomy is identified as a 
preferred value (Schaefer, Kahane, and Savulescu, 2014). Nootropics can be considered as a human enhancement technology, because (1) nootropics increase (inter alia) IQ, (2) giving more people the opportunity to increase their IQ will lead to (inter alia) more equality, and (3) equality is identified as a preferred value.

Assuming unequivocal humanist criteria for what can be considered "enhancement" and "enhancement technology" secures that a person can radically transform him- or herself and essentially still remain the same person, as also indicated by the transhumanist presumption of continuity between the over-abled and differently-abled. Although transhumanists are in favour of altering and therefore "violating" human nature (which is not in line with certain bioconservative humanist views), they believe that this altering will not lead to a "violation" but rather to a more effective realization of humanist aspirations. This is why transhumanists' "humanism" is a "humanism plus." The differently-abled could have more and different functions and capacities_-which are brought about by certain technological interventions - than the over-abled but will share and even better realize the same, unequivocal humanist values, goals, and ideals. The posthuman is in fact a superhumanist.

This view is highly problematic, because transhumanists covertly assume the possibility of a priori criteria for what the human is and ought to be, criteria falling outside of and, therefore, not affected by the empirical realm. However, Nietzsche's notion of the Overhuman and his conception of the human being as the "not yet determined animal" disclose such conceptions as modern manifestations of yet another attempt to turn the human "into a mummy," capturing him with "mummified concepts" (Nietzsche, 2007, 167). Transhumanists reduce the human being to characteristics (faster, stronger, smarter) that they find ideal in their current era and scope. Their lack of historical and phenomenological sense prevents them from seeing that all criteria used to establish what the human is or should be are context- and time-bound. Also, the meaning of concepts such as "free," "rational," and "tolerant" that are attributed to the transhumanists' ideal human being are very much dependent on their (technological) framing of the human.

What is decisive here is not the question of whether technology $\mathrm{z}$ can really improve capacity y, which in its turn can contribute to realizing value $\mathrm{x}$. Let us assume that there is or will be sufficient empirical support for those hypotheses. The crucial point here is that transhumanists fail to see how much their conception of the human is influenced by their scope of interest, namely, existing and emerging technologies, and their technological vocabularies. These technologies are not neutral but rather "norm," explicitly or implicitly, what is considered as a "human" and what is meant by "enhancing human capacities" and "optimizing values" (Aydin, 2015).

This point sheds a completely different light on the causal relations that are drawn between values, capacities, and technologies. Let us reflect again 
on the particular technologies mentioned earlier. A brain implant for extra information storage, which presumably would improve memory, is not a neutral technology but rather expresses, feeds into, or brings about a particular conception of "memory" and "rationality": memory is interpreted as "processing and retrieving information," which are characteristics that are normally attributed to computers. Improving rational thinking is then to a great extent interpreted in terms of faster processing and retrieving greater amounts of information. Rational thinking, hence, is believed to be computational in nature. Transhumanists (and many other people) do not seem to realize that this conception arose only in the 1940s and 1950s (Sternberg and Sternberg, 2012).

Genetic modification (a.k.a. genetic engineering), which presumably would improve deductive/logical competence, is not a neutral technology but rather expresses, feeds into, or brings about a particular conception of competence and autonomy: genetic engineering is compared to (re)programming DNA in cells. The concept of gene (re)organization then corresponds to the arrangement of "files" in a computer system, which are part of an information processing system. In a recent paper (Haraway, 1991; Chen et al., 2013), the formalism of chemical reaction networks is used as a "programming language." Sometimes the genetic code is considered to be a (quaternary) digital code. Gene (re)organization, it is believed, will then directly or indirectly affect mental rules, models, and algorithms, which in their turn will improve computational capacities. Improving autonomy is also in this case interpreted in terms of increasing computational competence.

Nootropics, which presumably would improve IQ, are not neutral technologies but rather express, feed into, or bring about a particular conception of intelligence and equality: nootropics are believed to affect brain function (e.g., by strengthening synapses between neurons and underlying synaptic plasticity or by increasing blood circulation) and improve mental functions such as memory and concentration. These and related functions are operationalized in IQ-tests in indices as "recognizing similarities," "picture completion," and "digital symbol coding." Intelligence is again framed in terms of "processing and retrieving information" and quantified as a score. Enabling people to increase this score, some transhumanists believe, could contribute to more equality. However, psychologists such as Stanovich (2009) have argued that IQ tests reduce "intelligence" to a particular selection of traits and identify it in terms of what the test can measure. These tests fail to assess skills, such as judgment and decision making, that most people associate with "good thinking."

Recognizing how technologies "norm" and have always normed conceptions of the (ideal) human discloses copious variations of criteria, both diachronic and synchronic, for what can be considered "enhancement." In their characterization of the posthuman being, transhumanists generalize and substantialize a current self-understanding of what a human being is and ought 
to be and, implicitly or explicitly, disregard other possible conceptions of "normal," "healthy," and "enhanced," and disqualify other possible (ideal) life forms.

Here, Nietzsche's criticism of evolutionary perspectives might also apply to transhumanism: not self-overcoming but rather self-preservation seems to be the transhumanists' goal. In Nietzsche's words: "They kill and stuff the things they worship, these lords of concept idolatry" (Nietzsche, 2007, 167). The standardization of the (ideal) human is nothing else than yet another echo of an essentialist metaphysics. This Nietzschean critique helps us to reveal how transhumanists wrongly assume that their criteria for determining what is an "enhanced being" are not affected by their particular understanding of the technologies on which they have pinned their hopes and their particular technological grammar, which allows them to believe that these criteria are a priori. What is considered "normal" and "healthy" is redefined in terms of what technologies are able to measure, diagnose, and treat. It is possible that what is now considered "normal" or "healthy" will increasingly be thought of as defective or disvalued as what transhumanists consider "enhanced states" become more the norm (Hanson, 1999).

From a psychological perspective, Nietzsche often interprets this essentialist tendency as a symptom of the inability to cope with the finitude and contingency of life and all our life projects. Transhumanists' goals such as self-preservation, longevity, equality, and happiness fit, therefore, much better in Nietzsche's characterization of the "last human" than in his portrayal of the Overhuman (Nietzsche, 2006, 10).

\section{The Disembodied and Disembedded Posthuman}

Nietzsche argues that essentialist philosophers like Plato disqualify the body and its senses due to their exhibition of multiplicity, change, and fluidity, and their inability to display eternal forms. In contrast to the ratio, the body and its senses are incapable of generalizing. Nietzsche attempts to turn, one might say, Plato upside down (Stack, 1983, 56). He repeatedly stresses the love of the Overhuman for the body and its senses (Hauskeller, 2010). His thinking "along the guiding thread of the body" displays humans as embedded and embodied creatures who due to their particular social contexts and specific material constitutions have often very individual, non-generalizable standards for what is "normal," "healthy," "good," or "ideal."

Here, we again encounter the problematic presumption of an unequivocal criterion for enhancement. This presumption, however, is now explained by transhumanists' "rational" (generalizing) Platonic approach. Transhumanists identify humans who lack certain functions or abilities, which are from their perspective essential, as "disabled" and presume that adding a function or capacity by virtue of technologies will make those humans able again. Give a well-functioning prosthesis to a person who has a leg missing, 
and he will be abled. Meanwhile, if abled and over-abled people are given additional functions or abilities, then, transhumanists believe, they become differently abled. So, if an abled person is given extra information storage that can be implanted into his brain, then he will become differentlyabled. Transhumanists tend to assume that their prospected technologies will affect humans in a similar, uniform way, and in so doing disregard the highly particular social and material circumstances of real-flesh and bones (and metal and code)—people. In contrast, Nietzsche's focus on the body and its embeddedness in a particular context indicates that people could respond in various and sometimes even opposing ways to certain technologies and could have very idiosyncratic standards for what they find "normal," "healthy," or "enhancing."

In her dissertation on "intimate technologies," Dalibert (2014) focuses on the way people embody technologies and shows how big the discrepancy is between the transhumanist qualification of certain aids as "enhancement technologies" and the way real persons of flesh and blood experience those aids. A prosthesis or a spinal cord stimulation device can indeed make people mobile again or make them function more efficiently. Whether those changes are experienced as "enhancement," however, is also dependent on how people bodily relate to those technologies. A woman interviewed by Dalibert confirms that with spinal cord stimulation she has much less pain and can move much more easily. At the same time, she indicates that she does not experience the device unambiguously as improvement. For example, she finds it very awkward that her husband can feel the pulse generator under her skin when they are in bed (Dalibert, 2014, 212).

How important the social context is can be further illustrated by divergent responses to a technology such as the cochlear implant. Although many people might consider a cochlear implant as "enhancement," there are members of the "deaf community" who do not embrace this technology. They believe sign language is their cultural cornerstone. Deaf children who receive cochlear implants at a young age will be less likely to be educated in sign language during their early years, which is seen by the deaf community as a loss of culture-one that, in some cases, has been passed down through generations (Ringo, 2013). There are also deaf parents that argue that they are entitled to have deaf children. One way of doing this would be to select a "deaf embryo" by using in vitro fertilisation and pre-implantation genetic diagnosis (Fahmy, 2011). In their social context cochlear implants are seen neither as enhancement, nor as normal or healthy, but rather as deterioration.

Nietzsche's critique of unequivocal criteria for what can be considered "normal" and "ideal" prompts us to go even further: it is even possible that in one context or one period in history, $\mathrm{x}$ is considered as enhancement, whereas in another context or other period in history the opposite of $\mathrm{x}$ is seen as enhancement. "Faster, stronger, smarter" might be ideal in our era. In other eras or other contexts "slower" (e.g., the wise man who reads and 
"processes information" slowly), "weaker" (e.g., the passivist who prevents a war), "simpler" (e.g., the holy "idiot" who knows no resentment) could qualify as enhancement, depending on how those notions are framed. The same criticism could be applied to the main values of transhumanists: rationality can also be interpreted as cold calculation and as an antonym of affection. Autonomy can be interpreted as egoism and as a danger to communal bonds. Equality can be interpreted as levelling everybody down to the same common denominator and as a destroyer of all competition and motivation.

This critique can be further refined from the perspective of Nietzsche's "will to power": it is in the struggle of different standards that the 'realities' that are set by these standards emerge and gain meaning and significance. Let me clarify by an example: probably there was no other time in which there was so much struggle about how to understand and apply the Bible than the Middle Ages. However, it was by virtue of this struggle that the Bible in the Middle Ages was "real" and had meaning and significance. The Bible loses its significance in secularized times not because it has been repudiated in a struggle of interpretations, but because there is no struggle anymore about how to interpret it. In other words: the Bible has not been repudiated, but it has become irrelevant.

These and similar cases make clear that understanding "enhancement" from one (trans)humanist perspective and envisaging a posthuman being with certain extraordinary features is only possible if the multiplicity that characterizes the lives of real human beings is disregarded, separating people's (rational) "souls" from their material and social contexts. However, historical and phenomenological inquiry shows that people are, in Nietzsche's words, no "thinking frogs, no objectifying and registering devices with frozen innards" but reliant on and moved by "blood, heart, fire, pleasure, passion, agony, conscience, fate, and disaster" (Nietzsche, 2001, 6). For some people and in certain circumstances, realizing certain goals in the most efficient way might be the decisive criterion for "enhanced." Other people in other circumstances, however, might find social, emotional, or aesthetic criteria much more important.

From a more psychological point of view, Nietzsche often interprets this "human, all too human" tendency to disembody and disembed the (post) human being again in terms of an inability to cope with and take responsibility for life as it is. With no realm of "objective judgments," "goods in themselves," or any "natural right," (weak) human beings experience a finite, temporally mutable, contextual, and contingent life as an unbearable burden or curse that requires redemption (Nietzsche 2006, 76-79). Transhumanists want life, but they cannot cope with life as it is, with all its trouble, mess, banality, and limitations. They want a "body," but they cannot cope with a body that might suffer, get ill, or die (Babich, 2012, 35). Nietzsche's ultimate response to this tendency to deny and escape "real life" is a radical, allencompassing Yes-saying to life, which finds its completion in the willing of the eternal recurrence of the same (Müller-Lauter, 1999, 248f). 
The Autotheist Posthuman

Besides "invariability" and "uniformity," a third aspect characterizes essentialist approaches, namely, "independence." In modern Western philosophy, especially that influenced by Descartes and Kant, "independence" has been strongly associated with "autonomy." The capacity for autonomy, according to Kant, is "the basis of the dignity of human and of every rational nature" (Kant, 2003, 53). The ability to determine and govern ourselves is not only seen as an essential characteristic of the human being, but also as the highest intrinsic value to which we should aspire.

Transhumanists not only adopt this Enlightenment ideal of taking control of our own lives but also redefine it from the perspective of emerging technologies: we could truly liberate ourselves from the restrictions of our body and mind if we were able radically to modify our biology according to our wishes and, hence, completely control it. In Kosko's words: "Biology is not destiny. It was never more than tendency. It was just nature's first quick and dirty way to compute with meat. Chips are destiny" (Kosko, 1999, 256). Kevin Warwick declares: "I was born human. But this was an accident of fate- a condition merely of time and place. I believe it's something we have the power to change" (Warwick, 2000, 145).

In addition, many transhumanists believe this notion of an autonomous self fits in the liberal or even the libertarian view that each individual is the final arbiter of what is right and appropriate for his life or body. Transhumanists not only claim that emerging technologies will enable us to optimize and expand our mental and bodily capacities, but they will also allow us to emancipate ourselves from (governmental) authorities that limit our freedom. We will be able to design our lives as we please. The posthuman is master and commander of his own fate.

At first sight, this notion of the posthuman seems to resemble Nietzsche's idea of the Overhuman. The figure of the Overhuman also urges people to detach themselves from oppressing forces (especially from mediocrity and the status quo!) and to become sovereign beings. On reflection, however, Nietzsche's Overhuman poses very different conditions for overcoming limitations from the transhumanists' view. From a Nietzschean point of view, "overcoming limitations" does not mean finding new (technological) ways to improve capacities that could contribute to realizing certain values set by a particular (in this case: humanist) value system. The Overhuman rather challenges the inevitably "limiting scope" of every particular worldview and value system and their criteria for establishing what is an (ideal) human being. That explains, as indicated before, why Nietzsche is unable to provide any description of the Overhuman and why envisaging an ideal human being as a "current human being + extraordinary characteristics" is not sufficient to radically transform the human being. 
The elaborated view of the Overhuman as an index of transcendence is an attempt to express this paradoxical challenge. Recognizing a dimension in human existence that in no way can be controlled, appropriated, or domesticated, is a necessary condition for radical self-transformation. By virtue of this transcendent dimension, the human can never completely coincide with his current state, which is a conception that is also expressed by Nietzsche's idea that the human being can never be completely determined. Radical self-transformation is only possible if the anticipated ideal in no way can be reduced to the current (and past) self-understanding of the human being. Transhumanists who claim that the human being will be able completely to design his life and fate deny this transcendent dimension and necessarily reduce, in their projections of an ideal human being, the human to a contemporary (humanist) perfect image, to an idol. The human being has from their view no other goal beyond himself.

In contrast to the transhumanists' autotheist posthuman, the Nietzschean "ideal" is a much less convenient and reassuring idea. The metaphor of the tightrope walker in Also sprach Zarathustra, who "lost his head and the rope" and "threw away his pole and plunged into the depths even faster than his pole" (Nietzsche, 2006, 11) shows that success is not guaranteed. At least, it is naïve to assume that adopting new and emerging technologies will not affect our standards for determining what is "normal," "healthy," and "enhanced." Transhumanists should take into account that in following unknown paths we even could end up throwing overboard the very (humanist) ideals that impel us to enhance our lives. Overcoming and therefore "violating" human nature could indeed come with "violating" the humanist value system.

Some technologies that are available today already affect our current standards. Cochlear implants, for example, challenge common ideas about what is "normal hearing" and instigate intense debates and serious disagreements about what is "enhancement." Moreover, imagine cochlear implants that would allow people to hear relevant "sounds" that are completely beyond the reach of "normal" hearing. Would our traditional standards for "bad" and "good hearing" then still suffice? I think not.

Cochlear implants also challenge common views about agency. If somebody "wears" a cochlear implant, then who/what hears and, hence, who/ what can be considered the "agent of hearing:" the human being, the cochlear implant, or (and that would be my best guess) the "synthesis of human being and implant"? Transhumanists consider technological developments as transparent and as always under control of humans without taking into account the possibility of technologies becoming "actants" themselves and co-shaping both human subjectivity and the world.

Radical self-transformation implies accepting the possibility that in adopting new technologies the very notion of what is an (enhanced) human being will be revised. Being susceptible to this possibility means accepting that we are not autonomous masters and commanders of our fate. In their depiction 
of the posthuman being, transhumanists illustrate, yet again, how comfortably essentialist their view of the human being is, a "comfort" that in reality disguises and suppresses fear for radical change and an unknown future. Paradoxically, the Nietzschean conception of self-transformation seems a better basis for the singularity idea. That we are "a bridge and not a purpose" (Nietzsche, 2006, 7) comes with the uncanny possibility that we will not be the ones who will cross that bridge.

\section{CONCLUSION}

Transhumanists envisage a development from abled to over-abled human beings, evolving in their turn into differently-abled human beings, who eventually could become posthumans. Nietzsche's notion of the Overhuman has been used as a "tuning fork" to "hear" whether transhumanists escape an essentialist conception in which one particular view of the enhanced or ideal human being is rendered absolute, disregarding how people in different contexts experience a "normal," "healthy" or "ideal" life form.

At first sight, the transhumanists' visualisations of radical self-transformation, as expressed by terms like "the singularity," seem to fit into an anti-essentialist anthropology. On reflection, however, their view of the posthuman only allows for a very specific and restricted "radical" change and variety. It displays the three main aspects that, throughout the history of philosophy, have been characteristic of an essentialist anthropology. Their posthuman is essentially invariable because they assume that their criteria for establishing what is enhancement are pre-given and, therefore, not susceptible to change, and disregard the fact that their ideal human being is "normed" by the technologies on which they pin their hopes. Their posthuman individual is essentially uniform because they believe that they can presume a general notion of enhancement, overlooking that, due to very different material and social conditions, human beings respond in various and sometimes even opposing ways to technologies and have very particular standards for what they consider as "enhancement." Their posthuman being is essentially independent because they think that, irrespective of the profound influence of emerging technologies, human beings are and can be in total control of their fate, disregarding the fact that radical transformation might be impossible without the demise of the present human being and his values and norms.

This Nietzschean scrutiny of the posthuman being discloses the transhumanists' ideal as a hollow idol that "rob[s] reality of its meaning, value, and truthfulness." Transhumanists' univocal criteria deny the boundless (present and future) potential multiplicity that can be found in the real world. The more practical implication of this observation is that, first, transhumanists are unable to do justice to how people in different contexts 
and settings experience and conceptualize "normal," "healthy," and "enhanced." This way they, implicitly or explicitly, disqualify standards that people have in everyday life. Second, in portraying the ideal human being as a "current human being + certain extraordinary features," transhumanists do not anticipate radical transformation, but rather strive to maintain the human being in his present state. Transhumanists are, therefore, not able to account for radically new or alternative life forms. Third, in assuming that our current basic standards will also apply to the posthuman, transhumanists portray a too cosy picture of the future, disregarding the possibility that in embracing new and emerging technologies we might be forced to challenge and maybe even give up our most cherished values and norms.

In this paper, I have only focused on the question of whether Nietzsche's conception of the Overhuman can reveal certain unfounded, unsound, or tenuous aspects in the transhumanists' ideal, disregarding the dispute between transhumanists and bioconservatives. However, this assessment has far-reaching implications for how to evaluate the positions of both camps. On the one hand, the transhumanists' ideal seems to be much more conservative than they realize, which brings them closer to bioconservatives than they think. Transhumanists assume that their standards for "normal," "healthy," and "enhanced" are generalizable and, hence, basically independent of how different people in different contexts experience and value "enhancement" technologies. On the other hand, the transhumanists' depiction of the posthuman being is much too reassuring, which challenges us to reflect more seriously on the incentives and implications of the possible impact of emerging technologies and radical self-transformation.

A genuine anti-essentialist view of the posthuman urges us to reflect fundamentally on what a "not yet determined animal" is for the human being and his future. In the light of emerging technologies, this idea is no longer a theoretical question for bored academics but a very existential one. What frightens both bioconservatives and transhumanists (as well as other people) most might not be emerging technologies and the possible risks that they bring with them, but rather the ever stronger awareness that the human being-having no essence, firm ground, or final telos-is a "monster and an abyss," that is, a being that escapes every possible uniform categorization and, therefore, continuously challenges and disrupts what some or even most people consider as "normal," "healthy," and "enhanced." What is "normal," "healthy," and "enhanced" seems to be very much dependent on particular contexts and life styles. Moreover, a proper assessment of how people respond to "enhancement technologies" like prosthetics, implants, and pharmaceutical drugs requires taking into account other criteria besides efficiency and functionality. 


\section{NOTES}

1. See, among other publications, the 2010 special issue "Nietzsche and European Posthumanisms" in the Journal of Evolution \& Technology. In a special issue of the journal The Agonist in 2012, four Nietzsche scholars renewed this debate.

2. I will also disregard Nietzsche's own views of technology, which consist of scattered remarks in predominantly the works of his middle period (1876-1882). Although Nietzsche sometimes mentions particular technologies (such as the steam engine, the rail-way, the telegraph), his main focus is on how modern technology organizes society and, especially, affects human creativity. It is of note that Nietzsche's attitude toward technology is ambivalent: technology could be a source for creative growth but also cause inertia and decay (McGinn, 1980). These views are interesting but of no significant relevance for the theme of this paper.

3. See Brey (2008) for a categorization.

4. In most transhumanists' writings the meanings of the terms "normal" and "enhanced" are unclear. Often transhumanists (implicitly or explicitly) understand "normal" in the sense of statistical distribution within a population: the distribution of a trait is "normal" if most individuals are clumped in the middle of the distribution curve with some outliers. They then almost always assume that the categories "normal," "healthy," or "enhanced" are descriptive and do not require further analysis (Marsh, 2006). The aim of this paper is not to challenge (bio)statistical framings of "normal" or "healthy" but to show how transhumanists' conceptions of these terms are influenced ("normed") by their particular understanding of the technologies on which they have pinned their hopes and to make clear why that is problematic.

5. For pragmatic reasons, I refer to the "human (being)" with third person singular masculine adjectives or pronouns (his/him/himself). "Human (being)" includes, of course, both (or multiple) sexes.

6. Modern theologians increasingly hold to the view that the human being is an indissoluble unity of mind/soul and body (Milne, 1982, 120-122). From their point of view, Nietzsche's critique of soul/ mind-body dualism might be more applicable to Platonist and Cartesian thought than to Christian.

7. Sparrow (2007) develops a similar argument in relation to nanotechnology.

\section{REFERENCES}

Aydin, C. 2003. Zijn en Worden. Nietzsches Omduiding van het Substantiebegrip. Maastricht, The Netherlands: Shaker Publishing.

- 2007. Nietzsche on reality as will to power: Toward an "organization-struggle" model. Journal of Nietzsche Studies 33:25-48.

2008. The struggle between ideals: Nietzsche, Schmitt, and Lefort on the politics of the future. In Nietzsche, Power \& Politics: Rethinking Nietzsche's Legacy for Political Thought, eds. H. W. Siemens and V. Roodt, 801-17. New York: De Gruyter.

— 2015. The artifactual mind: Overcoming the "inside-outside" dualism in the extended mind thesis and recognizing the technological dimension of cognition. Phenomenology and the Cognitive Sciences 14:73-94.

Babich, B. 2012. Nietzsche's post-human imperative: On the "all-too-human" dream of transhumanism. The Agonist [On-line]. Available: http://www.nietzschecircle.com/ AGONIST/2011_08/Dream_of_Transhumanism.pdf (accessed February 12, 2017).

Bostrom, N. 2002. Existential risks: Analyzing human extinction scenarios and related hazards. Journal of Evolution E Technology 9 [On-line]. Available: http://www.jetpress.org/ volume9/risks.html (accessed February 12, 2017).

- 2003a. Human genetic enhancements: A transhumanist perspective. Journal of Value Inquiry 37:493-506.

. 2003b. The transhumanist FAQ: v 2.1. World Transhumanist Association [On-line]. Available: http://www.nickbostrom.com/views/transhumanist.pdf (accessed February 12, 2017). 
2005. A history of transhumanist thought. Journal of Evolution \& Technology 14 [On-line]. Availible: http://jetpress.org/volume14/bostrom.html (accessed February 12, 2017).

- 2008. Why I want to be a Posthuman when I grow up. In Medical Enhancement and Posthumanity, eds. B. Gordijn and R. Chadwick, 107-36. New York: Springer.

- 2013. Existential risk prevention as global priority. Global Policy 4:15-31.

Bostrom, N. and R. Roache. 2008. Ethical issues in human enhancement. In New Waves In Applied Ethics, eds. J. Ryberg, T. S. Petersen, and C. Wolf, 120-52. New York: Pelgrave Macmillan.

Brey, P. 2008. Human enhancement and personal identity. In New Waves in Philosophy of Technology, eds. J. K. Berg Olsen, E. Selinger, and S. Riis, 169-85. New York: Palgrave Macmillan.

Chen, Y., N. Dalchau, N. Srinivas, A. Phillips, L. Cardelli, D. Soloveichik, and G. Seelig. 2013. Programmable chemical controllers made from DNA. Nature Nanotechnology 8:755-62.

Dalibert, L. 2014. Posthumanism and Somatechnologies: Exploring the Intimate Relations between Humans and Technologies. Enschede, The Netherlands: University of Twente CTIT PhD Thesis Series.

Fahmy, M. S. 2011. On the supposed moral harm of selecting for deafness. Bioethics 25:128-36. Garreau, J. 2005. Radical Evolution: The Promise and Peril of Enhancing Our Minds, Our Bodies-and What It Means to Be Human. New York: Broadway Books.

Habermas, J. 2003. The Future of Human Nature. Cambridge, United Kingdom: Polity Press.

Hanson, M. J. 1999. Indulging anxiety: Human enhancement from a Protestant perspective. Christian Bioethics 5:121-38.

Haraway, D. 1991. A cyborg manifesto: Science, technology, and socialist-feminism in the late twentieth century. In Simians, Cyborgs and Women: The Reinvention of Nature, ed. D. Haraway, 149-81. New York: Routledge.

Harris, J. 2007. Enhancing Evolution. Princeton, NJ: Princeton University Press.

Hauskeller, M. 2010. Nietzsche, the Overhuman and the posthuman: A reply to Stefan Sorgner. Journal of Evolution \& Technology 21 [On-line]. Available: http://jetpress.org/ v21/hauskeller.htm (accessed February 12, 2017).

Kant, I. 2003. Fundamental Principles of the Metaphysics of Morals, trans. T. M. Abbott. Rockville, MD: Arc Manor.

Kosko, B. 1999. The Fuzzy Future: From Society and Science to Heaven in a Chip. New York: Random House/Harmony Books.

Kurzweil, R. 2005. The Singularity is Near: When Humans Transcend Biology. New York: Penguin.

Marsh, J. L. 2006. To cut or not to cut? In Surgically Shaping Children, ed. E. Parens, 113-24. Baltimore: John Hopkins University Press.

McGinn, R. E. 1980. Nietzsche on technology. Journal of the History of Ideas 41:679-91.

Milne, B. 1982. Know the Truth: A Handbook of Christian Belief. Leicester, United Kingdom: IVP.

Moravec, H. 1999. Robot: Mere Machine to Transcendent Mind. New York: Oxford University Press.

More, M. 1990. Transhumanism: Towards a futurist philosophy. Extropy 6:6-12.

- 2010. The overhuman in the transhuman. Journal of Evolution \& Technology 21 [On-line]. Available: http://jetpress.org/v21/more.htm (accessed February 12, 2017).

Müller-Lauter, W. 1971. Nietzsche: His Philosophy of Contradictions and the Contradictions of his Philosophy, trans. D. J. Parent. Chicago: University of Illinois Press. 
1999. Über Werden und Wille zur Macht. Nietzsche-Interpretationen I. Berlin, Germany: De Gruyter.

Naam, R. 2004. More Than Human: Embracing the Promise of Biological Enhancement. New York: Joseph Henry Press.

Nietzsche, F. 1997. On the Genealogy of Morality, ed. K. Ansell-Pearson. Cambridge, United Kingdom: Cambridge University Press.

- 2001. The Gay Science: With a Prelude in German Rhymes and an Appendix of Songs, ed. B. Williams. Cambridge, United Kingdom: Cambridge University Press.

- 2002. Beyond Good and Evil, eds. R.-P. Horstmann and J. Norman. Cambridge, United Kingdom: Cambridge University Press.

- 2003. Writings from the Late Notebooks, ed. R. Bittner. Cambridge, United Kingdom: Cambridge University Press.

- 2006. Also sprach Zarathustra, eds. A. del Caro and R. B. Pipin. Cambridge, United Kingdom: Cambridge University Press.

- 2007. The Anti-Christ, Ecce Homo, Twilight of the Idols, eds. A. Ridley and J. Norman. Cambridge, United Kingdom: Cambridge University Press.

Parens, E., ed. 1998. Enhancing Human Traits: Ethical and Social Issues. Washington, DC: Georgetown University Press.

Ringo, A. 2013. Understanding deafness: Not everyone wants to be "fixed." The Atlantic [On-line]. Available: http://www.theatlantic.com/health/archive/2013/08/understandingdeafness-not-everyone-wants-to-be-fixed/278527/ (accessed February 12, 2017).

Savulescu, J. 2001. Procreative beneficence: Why we should select the best children. Bioethics $15: 413-26$.

Schaefer, G. O., G. Kahane, and J. Savulescu. 2014. Autonomy and enhancement. Neuroethics 7:123-36.

Sorgner, S. 2009. Nietzsche, the overhuman, and transhumanism. Journal of Evolution E Technology 20 [On-line]. Available: http://jetpress.org/v20/sorgner.htm (accessed February 12, 2017).

Sparrow, R. 2007. Revolutionary and familiar, inevitable and precarious: Rhetorical contradictions in enthusiasm for nanotechnology. NanoEthics 1:57-68.

Stack, G. J. 1983. Lange and Nietzsche. Berlin, Germany: Walter de Gruyter.

Stanovich, K. E. 2009. What Intelligence Tests Miss: The Psychology of Rational Thought. New Haven, CT: Yale University Press.

Stegmaier, W. 1977. Substanz. Grundbegriff der Metaphysik. Stuttgart-Bad Cannstatt, Germany: Frommann-Holzboog.

Sternberg, R. J. and K. Sternberg. 2012. Cognitive Psychology. 6th ed. Belmont, CA: Wadsworth.

Stock, G. 2002. Redesigning Humans: Our Inevitable Genetic Future. Boston: Houghton Miffin Company.

van Tongeren, P. 1989. Die Moral von Nietzsches Moralkritik. Bonn, Germany: Bouvier Verlag.

Warwick, K. 2000. Cyborg 1.0. Wired [On-line]. Available: http://archive.wired.com/wired/ archive/8.02/warwick.html (accessed February 12, 2017).

Wilsdon, J. and P. Miller, eds. 2006. Better Humans: The Politics of Human Enhancement and Life Extension. London, United Kingdom: Demos. 